\title{
IMMOBILIZED MUTANT STRAIN OF PSEUDOMONAS PICTORUM FOR THE DEGRADATION OF PHENOL IN WASTEWATER
}

\author{
SUBRAMANIAN CHITRA, GANESAN SEKARAN,' AND GOWRI CHANDRAKASAN* \\ Department of Biochemistry, and ${ }^{1}$ Department of Environmental Technology, \\ Central Leather Research Institute, Madras-600 020, India
}

(Received January 8, 1996; Accepted August 7, 1996)

\begin{abstract}
Phenols present in the wastewater discharged from many phenol based industries act as antimicrobial agents and hence biological treatment of phenol laden wastewater to a standard level prescribed by the Environmental Protection Agency is difficult. In the present investigation, a biocatalyst was developed by immobilizing cells of a mutant strain of Pseudomonas pictorum (MU 174) onto rice bran-based activated carbon. Phenol in wastewater was observed to be degraded up to $3 \mathrm{~g} / \mathrm{l}$ under batch studies. A removal of $99.9 \%$ of phenol in domestic wastewater was achieved at a hydraulic retention time (HRT) of $24 \mathrm{~h}$ with a biocatalyst packed reactor under continuous flow studies. The biocatalyst had a reasonable shelf life after its preparation and had the desirable recycle capacity.
\end{abstract}

Accumulation of alien chemicals that are unable to be assimilated creates toxicity both for flora and fauna and for human beings who eat fish which feed on food containing these chemicals. Phenol is one such chemical that causes alarm by this process of accumulation (17). Phenols are among the most common water pollutants, since it is one of the most widely used organic compound in existence (1). Phenol is the raw material for a variety of synthetic organic compounds like dyes, perfumes, pesticides etc. Phenols and substituted phenols are reported to be present in the wastewater from industries like textile, timber, paper and pulp etc. ( 9 , 14). Wastewater containing phenol needs careful treatment before it is discharged into the receiving water bodies especially if such water is used for drinking purposes.

Phenol in wastewater can be removed either by physical, chemical or biological methods. Biodegradation using micro-organisms is versatile, inexpensive and can

* Address reprint requests to: Dr. Gowri Chandrakasan, Department of Biochemistry, Central Leather Research Institute, Adyar, Madras-600 020, India. 
potentially turn a toxic material into harmless end products. If properly designed and operated, biological processes can realize total oxidation of organic matter so that there are no sludges that must be eradicated as a result of treatment. This is in contrast to physical or chemical methods that usually produce residues that must be eradicated by encapsulation or other similar methods (3). The versatility and adaptability that microbial degradation of hazardous wastes have demonstrated, makes it tempting to promise potentially too much in finding immediate solutions to our pollution problems and in meeting tighter effluent discharge standards. Aerobic Gram negative Pseudomonas (4) are the most widely used bacterial strains for treating various organic compounds. In addition to these strains various other microbial strains have also been studied with regard to their capacities to degrade phenol or phenolic compounds. These include Bacillus $(5,11)$, Acinetobacter (12), Candida (15,18), Trichosporon (10,16), Rhodotorula (13), and Fusarium flociferum (2).

In the present investigation, five Pseudomonas species were screened from which $P$. pictorum was selected due to its higher tolerance limit. $P$. pictorum was treated with NTG and a mutant strain designated as MU 174 was selected after screening. To improve the degradation potential as well as to prevent washout of cells, MU 174 was immobilized onto rice bran-based activated carbon. Phenol degradation by the mutant strain of $P$. pictorum (MU 174), and the biocatalyst prepared by immobilizing MU 174 onto activated carbon, was carried-out in nutrient medium. Economically viable and feasible sewage medium replaced the nutrient medium under continuous column studies. The storage of the biocatalyst and repeated usability of the biocatalyst were also studied.

\section{MATERIALS AND METHODS}

Source of micro-organism. Five Pseudomonas species were obtained from the culture collection, NCL, Pune, India. Namely, 1) P. resinovorans (NCIM 2599), 2) $P$. aeruginosa (NCIM 2074), 3) $P$. desmolyticum (NCIM 2028), 4) P. cruciviae (NCIM 2004), and 5) P. pictorum (NCIM 2077). Among these, P. pictorum showed greater resistance to very high concentrations of phenol and thus was selected for further studies (Table 1).

Table 1. Selection of Pseudomonas strains for phenol degradation.

\begin{tabular}{|c|c|c|c|c|c|c|c|c|c|c|}
\hline \multirow{2}{*}{$\begin{array}{c}\text { Serial } \\
\text { No. }\end{array}$} & \multirow{2}{*}{ Organism } & \multicolumn{9}{|c|}{ Phenol concentration in $\mathrm{mg} / 1,000 \mathrm{ml}$} \\
\hline & & 250 & 500 & 750 & 1,000 & 1,250 & 1,500 & 1,750 & 2,000 & $>2,000$ \\
\hline 1. & Pseudomonas pictorum (NCIM 2077) & + & + & + & + & + & + & + & + & + \\
\hline 2. & P. cruciviae (NCIM 2004) & + & + & - & - & - & - & - & - & - \\
\hline 3. & P. desmolyticum (NCIM 2028) & + & + & - & - & - & - & - & - & - \\
\hline 4. & P. resinovorans (NCIM 2599) & + & + & + & + & - & - & - & - & - \\
\hline 5. & P. aeruginosa (NCIM 2074) & + & + & + & + & - & - & - & - & - \\
\hline
\end{tabular}

+ , presence of growth; --, absence of growth. 
Selection of mutant. After extensive screening, a mutant strain of $P$. pictorum MU 174 was selected according to the method of Chitra et al. (7).

Preparation of "biocatalyst." The biocatalyst was prepared by immobilizing cells of strain MU 174 onto rice bran-based activated carbon according to the method of Chitra et al. (6). The optimum conditions needed for the immobilization of MU 174 onto activated carbon are shown in Table 2.

Batch studies. The composition of the nutrient medium used for batch studies was the same as that used by Chitra et al. (7). Phenol was estimated after removing the cells by filtration using 4-amino-antipyrine according to the standard method of analysis (8). Bacterial growth in terms of cell mass was determined by measuring the optical density at a wavelength of $600 \mathrm{~nm}$.

Continuous column studies. A diagram of the glass reactor used for the continuous treatment process is shown in Fig. 1. The activated carbon loaded with the cells was packed to a volume of $250 \mathrm{ml}$ in a glass column. The degradation of phenol by the loaded cells was studied under different hydraulic retention time (HRT) of 6, 12, 24, and $48 \mathrm{~h}$. Four column runs were carried out at each HRT.

The feed for the continuous fermentation reactor was prepared by mixing a

Table 2. Optimum conditions for immobilization.

\begin{tabular}{ll}
\hline Cell concentration & $12.8 \times 10^{4}$ cells $/ \mathrm{ml}$ \\
Temperature & $30-34^{\circ} \mathrm{C}$ \\
$\mathrm{pH}$ & $6-9$ \\
Specific adsorption & $9.5 \times 10^{5}$ cells $/ \mathrm{g}$ \\
Glucose & $0.01 \mathrm{~g} / \mathrm{l}$ \\
Nitrate & $0.1 \mathrm{~g} / l$ \\
\hline
\end{tabular}

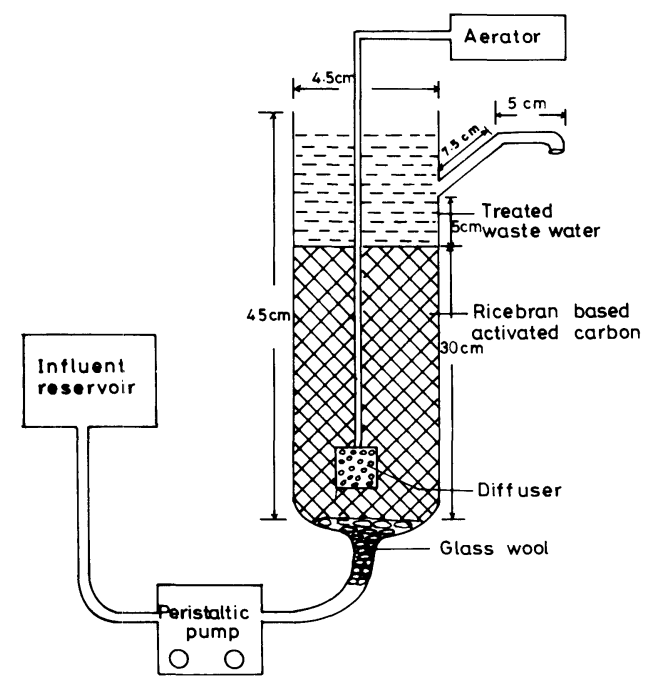

Fig. 1. Schematic flow diagram of continuous column reactor for the treatment of phenol laden wastewater. 
known concentration of phenol in a sewage medium. The preparation of sewage medium was according to that of Chitra et al. (7). The effect of the shelf-life of immobilized cells was tested by washing the column with distilled water.

\section{RESULTS AND DISCUSSION}

Batch studies on degradation of phenol by the biocatalyst

Figure 2 shows a phenol concentration-time-degradation diagram of the mutant $P$. pictorum immobilized onto rice bran-based activated carbon, i.e. the biocatalyst. The time required for start of degradation $\left(t_{\mathrm{s}}\right)$, time required for $100 \%$ degradation $\left(t_{\mathrm{f}}\right)$ and time for intermediate percentage of phenol degradation at various phenol concentration can be obtained from the diagram. To the left of the $t_{\mathrm{s}}$ curve, the phenol degradation does not occur and to the right of the $t_{\mathrm{f}}$ curve phenol in the medium is negligibly small, $t_{50}$ corresponds to time for $50 \%$ degradation of phenol. The biocatalyst initiated phenol degradation faster and was able to degrade $3,000 \mathrm{mg} / \mathrm{l}$ phenol. However, free cells of mutant MU 174 were able to degrade only up to $2,000 \mathrm{mg} / l$ phenol.

Studies on degradation of phenol under the continuous treatment process using biocatalyst

Application of specific cultures under field conditions become impracticable as they need specific nutrient mediums, whose degradation products also contribute to the pollution load of wastewater. Hence, an economically-viable and environ-

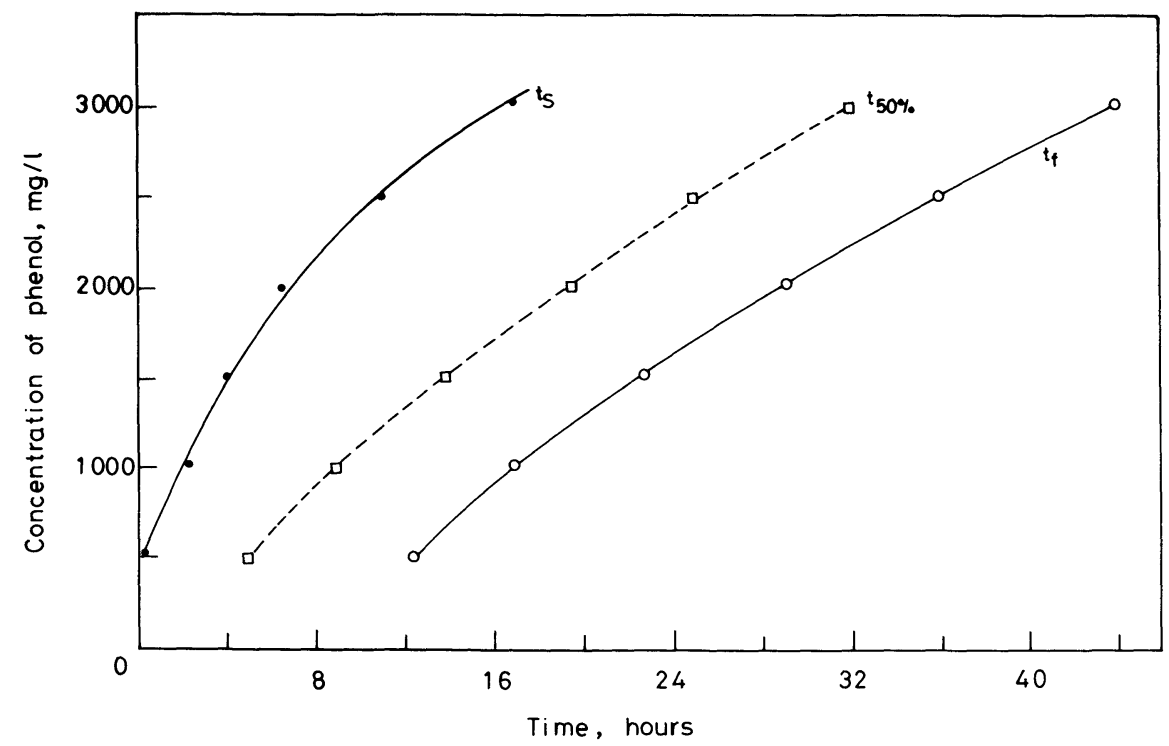

Fig. 2. A phenol concentration-time-degradation diagram for immobilized $\mathrm{MU}$ 174 cells in nutrient medium at $31^{\circ} \mathrm{C}$. 
Table 3. Characteristics of phenol-laden wastewater before and after aerobic treatment using immobilized MU 174 cells packed in an up-flow reactor.

\begin{tabular}{lccc}
\hline \multicolumn{1}{c}{ Parameter } & Before treatment & After treatment & \% Removal \\
\hline pH & 8.7 & 8.2 & - \\
Alkalinity & 120 & 110 & - \\
COD & 870 & 109 & 87 \\
BOD & 270 & 58 & 79 \\
Phenol & 500 & 0.5 & 99.9 \\
Dissolved solids & 345 & 40 & 88 \\
Volatile solids & 163 & 20 & 88 \\
\hline
\end{tabular}

Conditions of phenol loading rate $\left(0.5 \mathrm{~kg} / \mathrm{m}^{3}\right.$, day, hydraulic retention time $24 \mathrm{~h}$, dissolved oxygen in feed solution $8 \mathrm{mg} / l$ ) were used. COD, chemical oxygen demand; BOD, biological oxygen demand.

mentally-safe medium such as sewage was used for treating phenolic wastewater under continuous column studies.

A glass column packed with the biocatalyst was used for the continuous flow system at set HRT values. The results presented in Table 3 indicate that about 99.9\% phenol degradation was achieved in about $24 \mathrm{~h}$ HRT. The removal of chemical oxygen demand (COD) was in proportion to the removal of phenol in the sewage medium. At optimum HRT, the COD reduction was only $87 \%$ (Table 3), while phenol removal was about $99.9 \%$. The residual COD in treated wastewater was mainly due to the organic compounds contained in the sewage medium, and partly due to undegradable phenol. Removal of $88 \%$ dissolved solids (Table 3 ) was accompanied with elimination of phenol at optimum HRT.

Storage stability and repeated usability of the biocatalyst

If immobilization of cells was only onto the surface of the carrier material, the cells might be sloughed off by attrition during continuous treatment leading to a decreace in efficiency of the biocatalyst on phenol degradation. It was expected that immobilization of the organism was in pores of the activated carbon, which was explored by washing the column after each run ( $24 \mathrm{~h}$, set HRT). A negative result was obtained in the biological analysis of wastewater from the column. It is clear from Fig. 3, that the behaviour of the immobilized cell reactor for the degradation of phenol was not altered even with repeated usage. Therefore, the immobilized biocatalyst was subsequently used for phenol removal. The experiment did show that the biocatalyst had maintained its efficiency in percentage removal of phenol in wastewater.

The immobilized cells are advantageous in wastewater treatment due to easy transportation and storage. During storage and transportation, the immobilized organism is likely to be affected due to environmental alteration and thus the efficiency deteriorates. This fact is considered to be important while advocating the immobilized system for biodegradation or bioconversion of organics in wastewater. In the present study, as seen in Fig. 4, the same immobilized cells were able to 


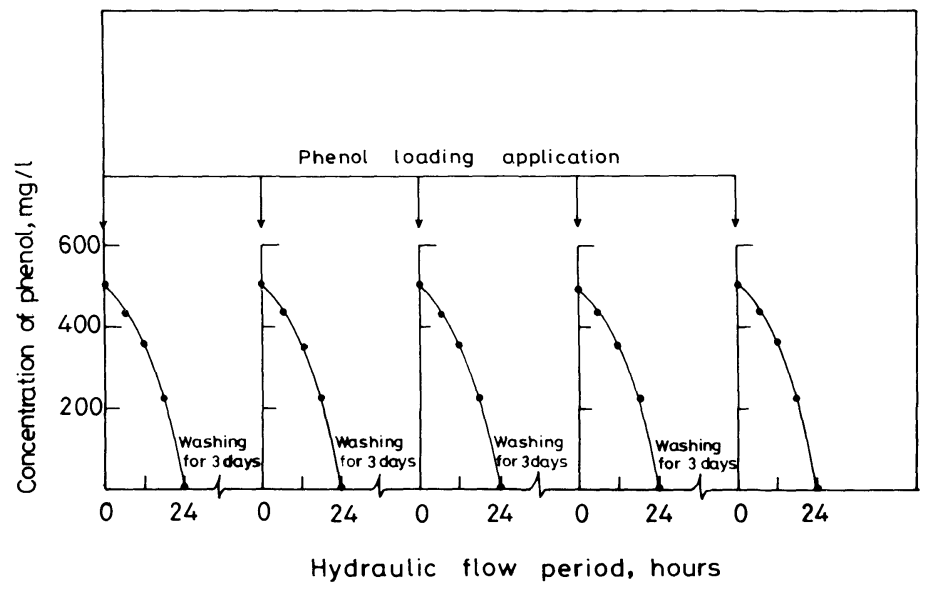

Fig. 3. Effect of washing of immobilized MU 174 cells on to activated carbon on degradation of phenol in sewage medium.

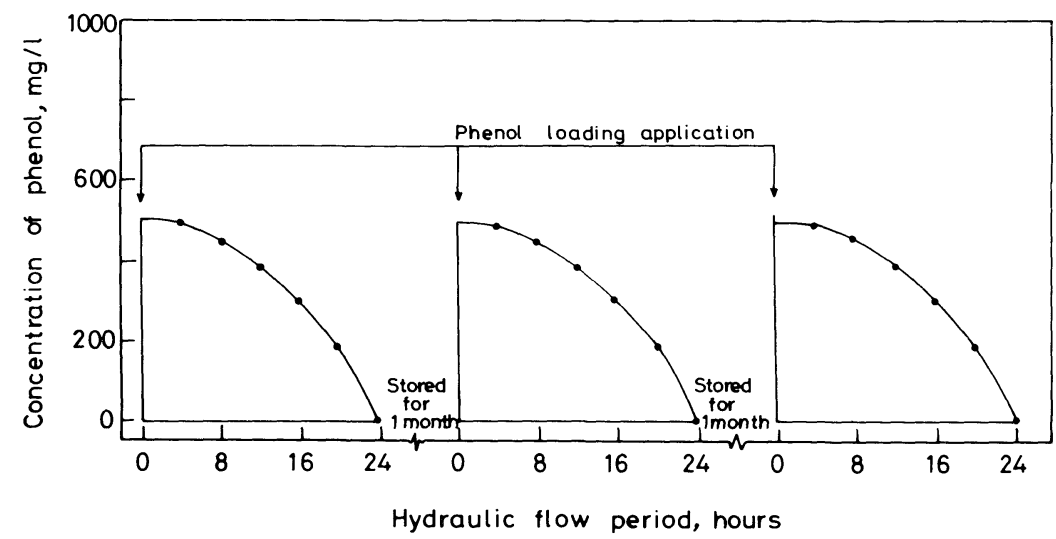

Fig. 4. Effect of storage of immobilized MU 174 cells on to activated carbon on degradation of phenol in sewage medium.

maintain their efficiency for three months. The efficiency of the immobilized cells was tested every month and remained the same as shown in the figure.

The storage stability and repeated usability of the biocatalyst, and the economically-viable and environmentally-safe sewage medium used for phenol degradation in a continuous column reactor packed with the biocatalyst, are considered to be the unique points of this method.

The authors are grateful to Dr. K. V. Raghavan, Director, CLRI for his keen interest in this work. Financial assistance by CSIR/UGC, is gratefully acknowledged by Miss S. Chitra. 


\section{REFERENCES}

1) American Chemical Society, Chemical and Engineering News, Key Chemicals and Polymers, 34th ed., Vol. 58, Washington, D.C. (1980).

2) Anselmo, A. M. and Novais, J. M., Isolation and selection of phenol degrading micro-organisms from an industrial effluent. Biotechnol. Lett., 6, 601-606 (1984).

3) Autenrieth, R. L., Bonner, J. S., Akgerman, A., Okaygun, M., and McCreary, E. M., Biodegradation of phenolic wastes. J. Hazard. Mater., 28, 29-53 (1991).

4) Bettmann, H. and Rehm, H. J., Degradation of phenol by polymer entrapped micro-organisms. Appl. Microbiol. Biotechnol., 20, 285-290 (1984).

5) Buswell, J. A. and Twomey, D. J., Utilization of phenol and cresols by Bacillus stearothermophilus strain pH 24. J. Gen. Microbiol., 87, 377-379 (1975).

6) Chitra, S., Sekaran, G., and Chandrakasan, G., Biodegradation of phenol in wastewater by immobilized mutant strain of Pseudomonas pictorum. J. Environ. Sci. Health, A30, 1749-1773 (1995).

7) Chitra, S., Sekaran, G., Padmavathi, S., and Chandrakasan, G., Removal of phenolic compounds from waste water using mutant strain of P. pitorum. J. Gen. Appl. Microbiol., 41, 229-237 (1995).

8) Clesceri, L. S., Greenberg, A. E., and Trussell, R. R. (ed.), Standard Methods for the Examination of Water and Wastewater, 17th ed., American Public Health Association, Washington, D.C. (1989), p. 5.48-5.54.

9) Dailey, N. S., Environmental Health and Control Aspects of Coal Conversion, Vol. 1, ed. by Braunstein, H. M., Copenhaver, E. D., and Pfunderer, H. A., Oak Ridge National Laboratory, TN (1977), chap. 4, p. 87.

10) Gaal, A. and Neujahr, H. Y., Induction of phenol metabolizing enzymes in T. cutaneum. Arch. Microbiol., 130, 54-158 (1981).

11) Gurujeyalakshmi, H. and Oriel, P., Isolation of phenol degrading Bacillus stearothermophilus and partial characterization of phenol hydroxylase. Appl. Environ. Microbiol., 55, 500-502 (1989).

12) Hashimoto, S. and Fujita, M., Identification of three phenol degrading micro-organisms isolated from the nature and their characteristics (in Japanese). J. Jpn. Sewage Works Assoc., 24, 27-33 (1987).

13) Katayama-Hirayama, K., Tobita, S., and Hirayama, K., Degradation of phenol by yeast Rhodotorula. J. Gen. Appl. Microbiol., 37, 147-156 (1991).

14) Lanouette, K. H., Treatment of phenolic wastes. Chem. Eng. (N.Y.), 84, 99-106 (1977).

15) Nei, N., Microbial decomposition of phenol (II) (in Japanese). J. Ferment. Technol., 49, 852-860 (1971).

16) Neujahr, H. Y. and Varga, J. M., Degradation of phenol by intact cells and cell free preparations of T. cutaneum. Eur. J. Biochem., 13, 37-44 (1970).

17) Renuka Devi, D. and Sastry, C. A., Toxicity of phenols to fish. Indian J. Environ. Prot., 7, 271283 (1987).

18) Stephenson, T., Substrate inhibition of phenol oxidation by a strain of Candida tropicalis. Biotechnol. Lett., 12, 843-846 (1990). 